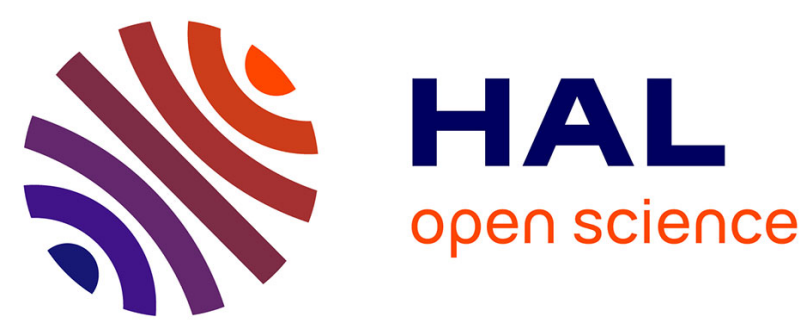

\title{
Changes of small strain shear modulus and microstructure for a lime-treated silt subjected to wetting-drying cycles
}

\author{
Zi Ying, Yu-Jun Cui, Nadia Benahmed, Myriam Duc
}

\section{- To cite this version:}

Zi Ying, Yu-Jun Cui, Nadia Benahmed, Myriam Duc. Changes of small strain shear modulus and microstructure for a lime-treated silt subjected to wetting-drying cycles. Engineering Geology, 2021, 293 (106334), pp.1-28. 10.1016/j.enggeo.2021.106334 . hal-03464918

\section{HAL Id: hal-03464918 \\ https://hal-enpc.archives-ouvertes.fr/hal-03464918}

Submitted on 3 Dec 2021

HAL is a multi-disciplinary open access archive for the deposit and dissemination of scientific research documents, whether they are published or not. The documents may come from teaching and research institutions in France or abroad, or from public or private research centers.
L'archive ouverte pluridisciplinaire HAL, est destinée au dépôt et à la diffusion de documents scientifiques de niveau recherche, publiés ou non, émanant des établissements d'enseignement et de recherche français ou étrangers, des laboratoires publics ou privés. 


\title{
Changes of small strain shear modulus and microstructure for a lime-treated silt subjected to wetting-drying cycles
}

\author{
Zi Ying ${ }^{1}$, Yu-Jun Cui ${ }^{1}$, Nadia Benahmed ${ }^{2}$, Myriam Duc $^{3}$
}

1: Ecole des Ponts ParisTech, Laboratoire Navier/CERMES, 6-8 av. Blaise Pascal, Cité Descartes, Champs-sur-Marne, 77455 Marne-la-Vallée cedex 2, France

2: INRAE, Aix Marseille Univ, RECOVER, Equipe G2DR, 3275 route Cézanne, CS 40061, 13182 Aix-en-Provence, France

3: Université Gustave Eiffel/GERS/SRO, 14-20 boulevard Newton, Champs-sur-Marne, 77447

Marne-la-Vallée, France

\section{Corresponding author:}

Prof. Yu-Jun CUI

Ecole des Ponts ParisTech, Laboratoire Navier/CERMES

6-8 av. Blaise Pascal, Cité Descartes, Champs-sur-Marne

77455 Marne-la-Vallée Cedex 2, France

Telephone: +33164153550

Fax: +33164153562

E-mail: yu-jun.cui@enpc.fr 


\begin{abstract}
:
Lime treatment can enhance the workability and hydro-mechanical properties of soil through different physical-chemical reactions. Nevertheless, the beneficiary effect of lime treatment can be altered when the soil was exposed to wetting-drying cycles, depending on the wetting fluid and soil state. In the present study, the changes in small strain shear modulus $\left(G_{\max }\right)$ and microstructure of a compacted lime-treated silt under wetting-drying cycles were studied. The untreated state of soil was also considered for comparison. Meanwhile, the effects of wetting fluid (deionized water and synthetic seawater) and maximum soil aggregate size $\left(D_{\max }=0.4\right.$ $\mathrm{mm}$ for S0.4 and $5 \mathrm{~mm}$ for S5) were investigated. Results showed that $G_{\max }$ increased significantly for the lime-treated soil over curing, and increased slightly for the untreated soil. The untreated specimens were softened and damaged by wetting-drying cycles, while the limetreated specimens exhibited good resistance with the pore size distributions almost kept reversible along the wetting-drying paths. The subsequent more intensive drying resulted in a significant fabric alteration with occurrence of shrinkage-related fissures of the clay part. However, these fissures were almost healed with rewetting. Thereby, the $G_{\max }$ of lime-treated soil showed a constant decreasing trend with wetting and an increasing trend with drying. Moreover, $G_{\max }$ decreased slightly with wetting-drying cycles for the lime-treated specimens wetted by deionized water, suggesting that the wetting-drying indeed softened the soil. However, $G_{\max }$ increased for the lime-treated specimens wetted by synthetic seawater, due to the more production of cementitious compounds promoted by salts. The lime-treated specimens S0.4 wetted by synthetic seawater had higher $G_{\max }$ than those wetted by deionized water, while the wetting fluid had insignificant effect on the $G_{\max }$ of specimens S5 due to the limited promotion of pozzolanic reaction and negligible soil aggregation induced by salts.
\end{abstract}

Keywords: Lime treatment; small strain shear modulus; microstructure; wetting-drying; wetting fluid 


\section{Introduction}

In most geological, geotechnical and geo-environmental applications, it is encouraged to use local soils in order to reduce the economic cost and carbon emission. When clayey soils are involved, they must be improved prior to use. Lime treatment was widely used in that case, allowing improvement of the workability and the hydro-mechanical behaviour of soils (Bell, 1989, 1996; Locat et al., 1990). It is generally accepted that lime hydration and cation exchange took place rapidly after mixing soil with water and lime, leading to the flocculation of soil particles (Guney et al., 2007; Al-Mukhtar et al., 2010a; Di Sante et al., 2014), and further improving the soil workability by reducing the soil plasticity, shrinkage, and swelling (Bell, 1996; Khattab and Fleureau, 2007; Al-Mukhtar et al., 2012; al-Swaidani et al., 2016). In the long term, the pozzolanic reaction developed, producing some cementitious compounds which coated the surface of aggregates and connected the adjacent soil particles (Bell, 1996). This resulted in an enhancement of soil mechanical behaviour, as evidenced by the increase of unconfined compressive strength (Al-mukhtar et al., 2010b; Muntohar et al., 2013), stiffness (Tang et al., 2011a; Wang et al., 2020) and shear strength (Sivapullaiah et al., 2000), and also by the decrease of compressibility (Rao and Shivananda, 2005; Vitale et al., 2017; Wang et al., 2017a).

Several studies reported that, as compared to the specimens prepared in the laboratory, the lime-treated soil in field condition usually exhibited lower strength and stiffness, but higher swelling potential and hydraulic conductivity (Puppala et al., 2006; Cuisinier and Deneele, 2008; Dong, 2013). This could be ascribed to the different sizes of aggregates used in the field and laboratory. Tang et al. (2011a) performed bender element tests on lime-treated soil with different maximum aggregate sizes and reported that the lime-treated specimens with smaller aggregates had higher small strain shear modulus $\left(G_{\max }\right)$. Wang et al. (2017b) reported that lime was more concentrated in the specimens with larger aggregates and formed well-crystallized cementitious compounds by pozzolanic reaction, while the distribution of lime was diffused in the small soil aggregate-lime mixture and poorly crystallized or amorphous cementitious compounds were produced in that case.

Even though the soil properties were improved by lime treatment, the long-term durability of lime-treated soils might be altered when the soils were exposed to cyclic climate loadings such as wetting-drying cycles. Several studies revealed that the imposition of wetting-drying cycles on lime-treated soil would partially destroy the cementitious bonds and alter the soil 
microstructure, leading to progressive loss of soil strength (Aldaood et al., 2014; Stoltz et al., 2014; Cuisinier et al., 2020; Nabil et al., 2020), and an increase in compressibility and hydraulic conductivity (Rosone et al., 2016, 2018; Cuisinier et al., 2020). Nevertheless, Anggraini et al. (2016) indicated that wetting-drying cycles could make the curing time longer, and therefore the durability of stabilized soils was enhanced. Similar strengthening behaviour was observed on untreated soil - $G_{\max }$ increased with increasing wetting-drying cycles due to the effect of suction history-related decrease of saturation degree and void ratio (Heitor et al., 2015; Ngoc et al., 2019; Khosravi et al., 2020). Estabragh et al. (2013) investigated the wetting fluid (distilled water, saline water and acidic water) effect on the volume change of swelling soil during wetting-drying cycles. They found that the specimens inundated with saline water and acidic water showed compressive deformation, while the specimens wetted by distilled water showed expansive deformation. To the authors' knowledge, there is no study focusing on the wetting fluid effect on the mechanical behaviour of lime-treated soils subjected to wettingdrying cycles.

Small strain shear modulus, $G_{\max }$ is an important parameter for describing the elastic properties of soils, and for predicting the dynamic response and deformation of geotechnical structures (Zhou and Chen, 2005; Ng and Yung, 2008; Tang et al., 2011a; Chakraborty et al., 2018). In this study, the changes of $G_{\max }$ with time were investigated using bender element method for a silt with two different maximum aggregate sizes $\left(D_{\max }=0.4 \mathrm{~mm}\right.$ and $\left.5 \mathrm{~mm}\right)$. Both untreated and lime-treated compacted specimens were prepared for this purpose. When the stabilization of $G_{\max }$ was reached, cyclic wetting-drying tests were performed with either deionized water or synthetic seawater as wetting fluid. At each wetting or drying stage, $G_{\max }$ was measured. Moreover, mercury intrusion porosimetry (MIP) tests were conducted on the lime-treated specimens which had been subjected to different wetting-drying cycles. The results obtained were analyzed to understand the changes of $G_{\max }$ during wetting-drying cycles for different wetting fluids and different maximum soil aggregate sizes.

\section{Materials and methods}

\subsection{Materials}

The tested soil was sampled at Les Salins de Giraud in southern France, which was used for a dike construction. According to the results obtained by Ying et al. (2021a), this soil was naturally saline with a soil salinity $\left(r^{\prime}\right)$ of $2.1 \%$ ( $\mathrm{g}$ of salt/kg of dry soil) and the corresponding 
water salinity of soil pore water is $13.3 \%$ ( $\mathrm{g}$ of salt $/ \mathrm{kg}$ of salty water) for the soil at $15.6 \%$ water content. The main ion species in soil pore water are $\mathrm{Cl}^{-}, \mathrm{Na}^{+}, \mathrm{K}^{+}, \mathrm{Ca}^{2+}$ and $\mathrm{Mg}^{2+}$. This soil has a liquid limit of $29 \%$, a plastic limit of $19 \%$ and a specific gravity of 2.71 . The specific surface area of soil is $24 \mathrm{~m}^{2} / \mathrm{g}$, which was measured by the spot test of methylene blue following the procedure proposed by Santamarina et al. (2002). The main minerals of this soil are quartz $(39 \%)$, calcite $(35 \%)$, feldspars $(9.5 \%)$, halite $\mathrm{NaCl}(0.8 \%)$, illite $(10.8 \%)$, chlorite $(3.6 \%)$ and kaolinite (1.3\%). The grain size distribution of natural soil is presented in Fig. 1. It is observed that the soil contains $17 \%$ clay-size particles $(<0.002 \mathrm{~mm}), 53 \%$ silt $(0.002 \sim 0.075 \mathrm{~mm})$ and $30 \%$ fine sand $(0.075 \sim 2 \mathrm{~mm})$.

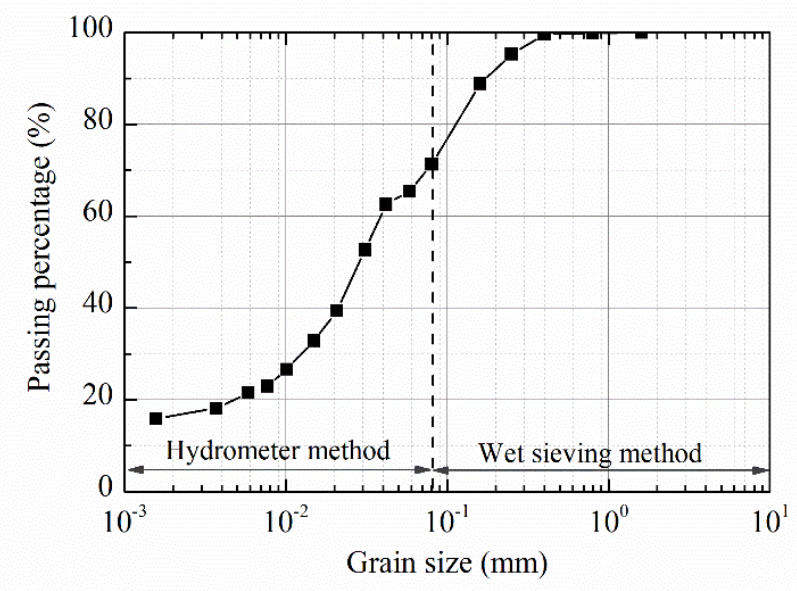

Fig. 1. Grain size distribution of the tested soil.

To prepare the soil specimens, the natural soil was air-dried, ground and sieved through two meshes with two different sizes of $0.4 \mathrm{~mm}$ and $5 \mathrm{~mm}$. Thus, two soil powders with different maximum aggregate sizes $\left(D_{\max }=0.4 \mathrm{~mm}\right.$ and $\left.5 \mathrm{~mm}\right)$ were obtained, namely S0.4 and S5, respectively. The soil aggregates were ground again until all the soil aggregates passed through, enabling the soil powders S0.4 and S5 to have the same mineral composition as natural soil.

A quicklime with $97.3 \% \mathrm{CaO}$ was used. The optimum lime dosage was determined by the $\mathrm{pH}$ method following the Eades and Grim test procedure (ASTM Standard D6276-19, 2019). The value was found to be $0.5 \%$ (by dry weight of soil) at which the $\mathrm{pH}$ of soil-lime-deionized water mixture reached 12.4. To keep consistent with the lime dosage in the dike construction at Les Salins de Giraud, a lime content of $2 \%$ was selected. 


\subsection{Sample preparation}

After the dry soil powders were prepared, 2\% lime was first mixed with dry soil. Then, deionized water was used to humidify the soil-lime mixture to reach different target water contents: $17 \%$ on dry side and $19 \%$ on wet side. Note that the dry side corresponded to the left side of optimum water content, while the wet side corresponded to the right side of optimum water content, as shown in Fig. 2. Note also that no water content higher than $19 \%$ was selected because water would flow out of soil during compaction at higher water contents. The soillime-water mixture was mellowed for $1 \mathrm{~h}$ to allow the development of rapid soil-lime reactions. Afterwards, static compaction was performed at a rate of $0.3 \mathrm{~mm} / \mathrm{min}$ to prepare the specimens at a target dry density of $1.63 \mathrm{Mg} / \mathrm{m}^{3}$ (Fig. 2). The specimens for bender element test had 50 $\mathrm{mm}$ diameter and $50 \mathrm{~mm}$ height, and the specimens for MIP tests had $50 \mathrm{~mm}$ diameter and 20 $\mathrm{mm}$ height. After compaction, the specimens were covered by paraffin to avoid water evaporation. Then, they were wrapped by plastic membrane and scotch tape, and cured in a hermetic box.

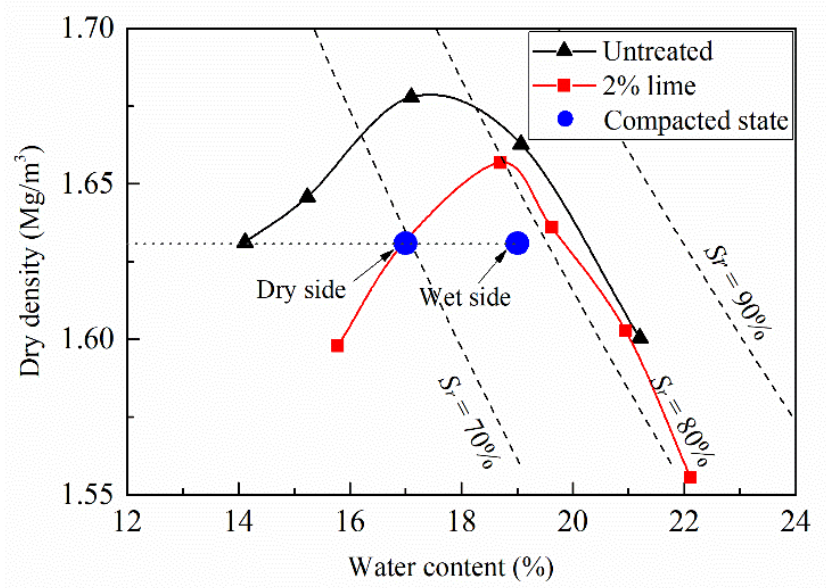

Fig. 2. Standard proctor compaction curves of untreated and lime-treated soils, as well as the soil states considered in the tests.

\subsection{Bender element tests}

The small strain shear modulus was measured by bender element technique (Fig. 3), which consists of a pair of piezo-ceramic elements, a function generator, an amplifier and an oscilloscope (Ying et al., 2021b). Prior to use, the bender elements were calibrated by connecting the two benders directly without soil sample. The delay time between two bender elements was found to be $2 \mu$ s that was considered in the calculation of travel time of shear 
wave through specimens.

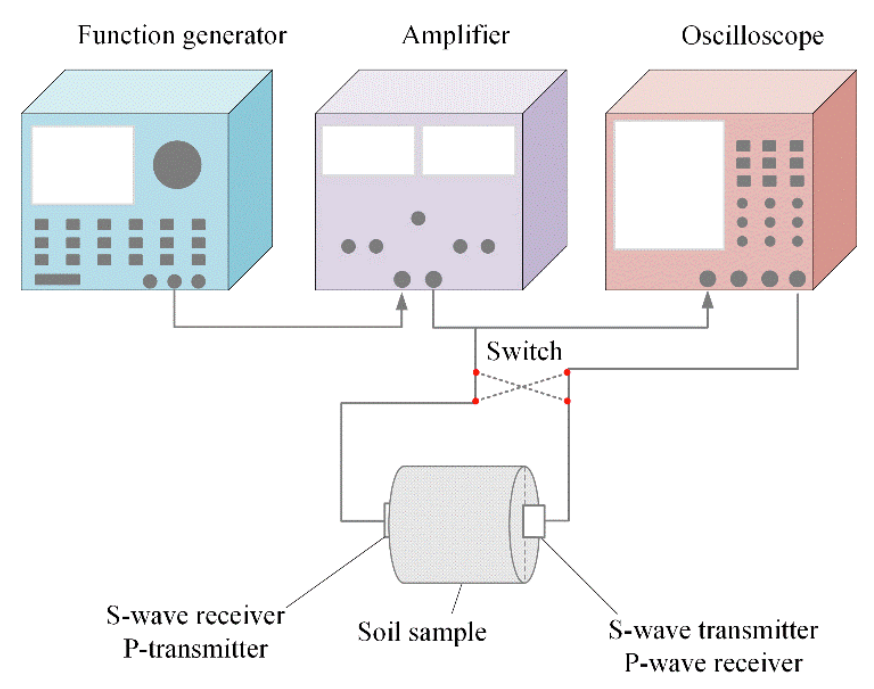

Fig. 3. Set-up of bender element test (after Ying et al., 2021b).

As the specimens for the bender elements tests were covered by paraffin, prior to testing, two slots were performed on the top and bottom surfaces of specimen with the same position to enable a good contact between the bender elements and specimen. The ground connection was applied during testing in order to eliminate the crosstalk and near-field effects (Lee and Santamarina, 2005). Afterwards, an excitation signal ( $\pm 14 \mathrm{~V}$ sine pulse) was emitted by the function generator and amplified by the amplifier. Both input (transmitted) and output (received) signals were acquired and visualized by oscilloscope. The arrival time of shear wave was determined by the $\mathrm{S}+\mathrm{P}$ method which needed to capture both the input and output signals of $\mathrm{S}$ wave and P-wave by oscilloscope through switching the connections of the two piezo-ceramic elements (Wang et al., 2017c). As shown in Fig. 4, Point $S$ was selected as the arrival point of shear wave, which corresponded to the initial main excursion (Point $S \_p$ ) in the received signal of P-wave (Wang et al., 2017c). Equation 1 was used to calculate the shear wave velocity $\left(v_{s}\right)$ :

$$
v_{s}=\frac{L_{t t}}{\Delta t}
$$

where $L_{t t}$ is the travel length (the height of specimen minus the depth of the two slots), $\Delta t$ is the travel time of shear wave (the arrival time minus the delay time between two benders). 


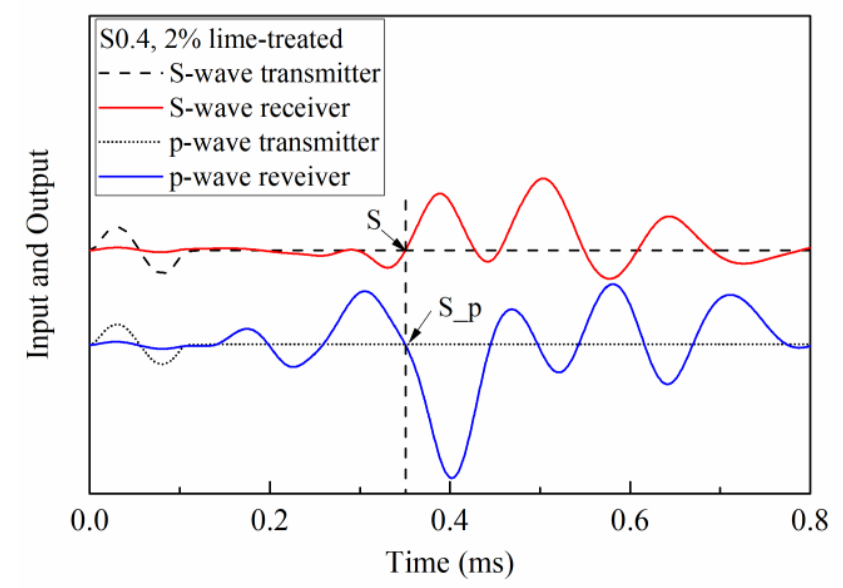

Fig. 4. Determination of the arrival point of shear wave by S+P method.

Equation 2 was used to determine the small strain shear modulus $\left(G_{\max }\right)$ :

$$
G_{\max }=\rho v_{s}^{2}
$$

where $\rho$ is the density of soil sample.

This $G_{\max }$ measurements were repeated on the same specimens over curing. Two replicated tests were conducted on the lime-treated specimens and four replicated measurements were performed on the untreated specimens. At a given time, the mean value of the measurements on the replicated specimens was used for further analysis.

\subsection{Wetting-drying tests for $G_{\max }$ measurement}

When the $G_{\max }$ kept stable with time, the wetting-drying cycles were applied on the specimens with deionized water and $35 \mathrm{~g} / \mathrm{L}$ synthetic seawater as wetting fluids. The salt composition of synthetic seawater is presented in Table 1 (AFNOR NF P 18-837, 1993). Prior to the wetting process, the paraffin on the top and bottom surfaces of the specimens was scraped off, allowing for water infiltration. Then, two filter papers and two porous stones were placed on the top and bottom sides, respectively. The specimens were wetted by adding water on the top surface using a plastic dropper until a constant mass of specimen was obtained. The water contents after wetting were found to be $21 \%$ for the lime-treated specimens, and $25 \%$ for the untreated specimens. For drying, the specimens were air-dried to the initial soil mass before wetting. At the end of the seventh wetting, the lime-treated specimens were subjected to an intensive drying to the water contents of $8 \%$ and $3 \%$. Afterwards, the lime-treated specimens were rewetted to the water content of $21 \%$. At the end of each wetting and drying stage, the specimens were 
wrapped in plastic film for at least $24 \mathrm{~h}$ for water equilibration. Then, $G_{\max }$ was measured by the bender element technique. The soil dimensions were measured using a calliper. Because the changes in soil volume were found to be negligible for the lime-treated specimens, they were ignored in the calculation of soil density and shear wave velocity. However, a swelling phenomenon was observed on untreated soil during wetting. Hence, the volume changes were considered in that case while calculating the soil density and shear wave velocity.

Table 1. Salt composition of synthetic seawater.

\begin{tabular}{cccccc}
\hline Salts & $\mathrm{NaCl}$ & $\mathrm{MgCl}_{2} \cdot 6 \mathrm{H}_{2} \mathrm{O}$ & $\mathrm{MgSO}_{4} \cdot 7 \mathrm{H}_{2} \mathrm{O}$ & $\mathrm{CaSO}_{4} \cdot 2 \mathrm{H}_{2} \mathrm{O}$ & $\mathrm{KHCO}_{3}$ \\
\hline Concentration $(\mathrm{g} / \mathrm{L})$ & 30.0 & 6.0 & 5.0 & 1.5 & 0.2 \\
\hline
\end{tabular}

\subsection{Wetting-drying tests for microstructure investigation}

The microstructure variations during wetting-drying cycles were investigated by Autopore IV 9500 mercury intrusion porosimeter. Because the microstructure of the studied silt was affected slightly by salts (Ying et al., 2021b) and the untreated soil was easily softened by wetting, only the lime-treated specimens S0.4 $\left(w_{i}=17 \%, t=600 d\right)$ were used for MIP tests, which were subjected to different wetting-drying cycles with deionized water as wetting fluid. Note that specimens S5 had the same microstructure variations as specimens S0.4. Thus, specimens S5 were not selected for MIP test for clarity. In total, eleven soil states of specimens S0.4 were considered for MIP tests (Fig. 5), which corresponded to the specimens' states for bender element tests. State "A" represented the as-compacted condition with an initial water content of $17 \%$ and dry density of $1.63 \mathrm{Mg} / \mathrm{m}^{3}$. After wetting, the water content of lime-treated specimens increased to $21 \%$. Then, the specimens were air-dried to the water content of $17 \%$. States "B", "C", "D", "E" and "F" corresponded to the ends of the first wetting (B), first drying (C), second wetting (D), seventh wetting (E) and seventh drying (F) cycles, respectively. Four specimens $(w=17 \%)$, after seven wetting-drying cycles, were subjected to more intensive drying to reach the water contents of around $8 \%(\mathrm{G})$ and $3 \%(\mathrm{H})$. Then, three specimens at water contents of $17 \%, 8 \%$ and $3 \%$ respectively were rewetted to the water content of $21 \%$, namely specimens "I", "J" and "K", respectively. The freeze-dried specimens were used for the MIP tests, which were rapidly frozen in liquid nitrogen and then dried with a freeze-dryer for 24h. 


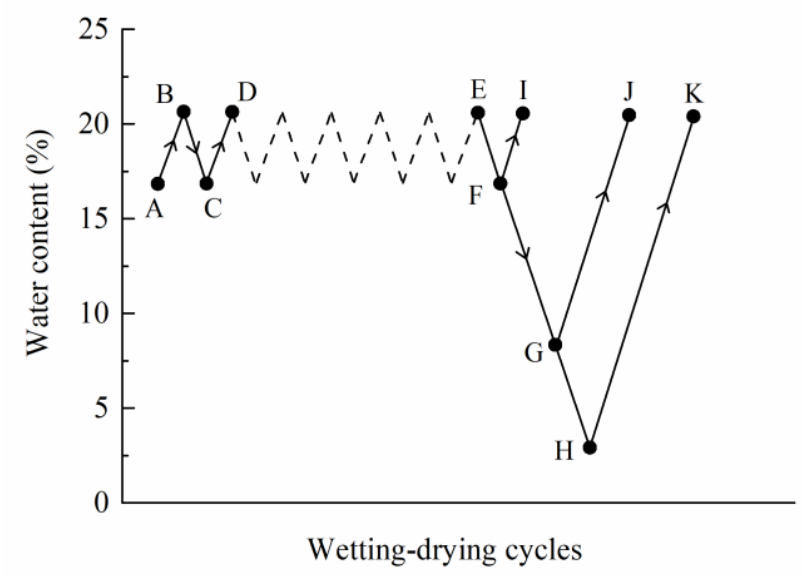

Fig. 5. The conditions of specimens for MIP tests.

\section{Results}

\subsection{Stiffness variations during curing time}

The variations of $G_{\max }$ are plotted against curing time on the semi-logarithmic scale for specimens S0.4 in Fig. 6a, and for specimens S5 in Fig. 6b. After compaction, the lime-treated specimens had higher $G_{\max }$ values as compared to the untreated specimens. $G_{\max }$ of the untreated specimens S0.4 and S5 increased slightly from $20 \mathrm{MPa}$ at $1 \mathrm{~h}$ to $23 \mathrm{MPa}$ at $2000 \mathrm{~h}$, while it increased much significantly for the lime-treated specimens. As shown in Fig. 6a, when the curing time was less than $100 \mathrm{~h}, G_{\max }$ of the lime-treated specimens $S 0.4$ compacted on dry side was higher than those of specimens S0.4 compacted on wet side. Upon further curing, $G_{\max }$ of the lime-treated specimens S0.4 compacted wet of optimum increased and approached the values of specimens compacted dry of optimum. Then, $G_{\max }$ increased with time and stabilized after $10000 \mathrm{~h}(417 \mathrm{~d})$ at around $60 \mathrm{MPa}$ (Fig. 6a) for the lime-treated specimens S0.4 on both dry and wet sides. In the case of lime-treated specimens S5 (Fig. 6b), $G_{\max }$ of the specimens on dry side was higher than those on wet side. Specifically, $G_{\max }$ increased from $26 \mathrm{MPa}(1 \mathrm{~h})$ to $59 \mathrm{MPa}(6900 \mathrm{~h})$ for the specimens S5 compacted dry of optimum, while it increased from 23 $\mathrm{MPa}(1 \mathrm{~h})$ to $49 \mathrm{MPa}(6700 \mathrm{~h})$ for the specimens S5 compacted wet of optimum. 

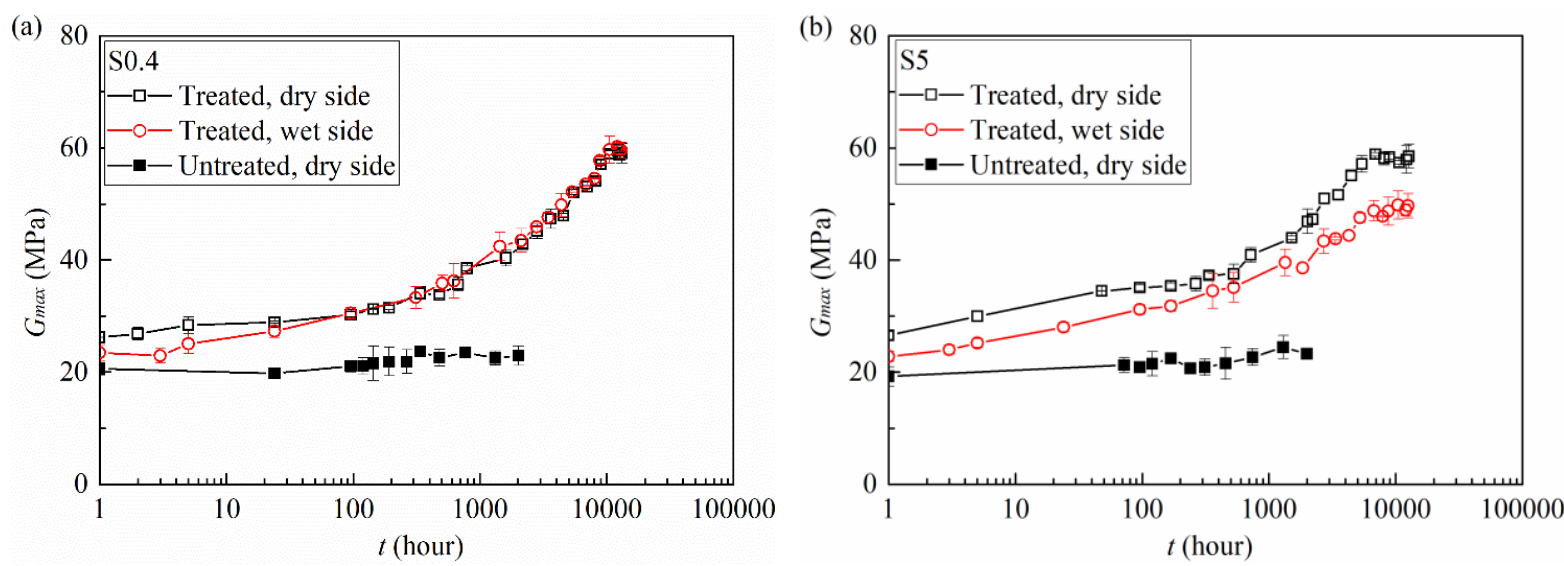

Fig. 6. Evolutions of small strain shear modulus after compaction: (a) S0.4; (b) S5.

\section{2 $G_{\max }$ variations under wetting-drying cycles}

The imposition of wetting-drying cycles had different effects on the morphology of untreated and lime-treated specimens. As shown in Fig. 7, some cracks initiated on the surface of untreated specimens after the first wetting. This was in agreement with the observations by Wang et al. (2014) on compacted bentonite, by Zeng et al. (2020) on compacted bentonite/claystone mixture, and by Zeng et al. (2017) on stiff Teguline clay. This phenomenon was attributed to the division of aggregates with wetting. Upon the second wetting, more and more cracks with larger width and length were observed on the untreated specimens. The third wetting cycle resulted in significant loss of soil and thus the destruction of untreated specimen. Nevertheless, the lime-treated specimens could well resist the wetting-drying cycles without appearance of any macro-cracks and specimen destruction.
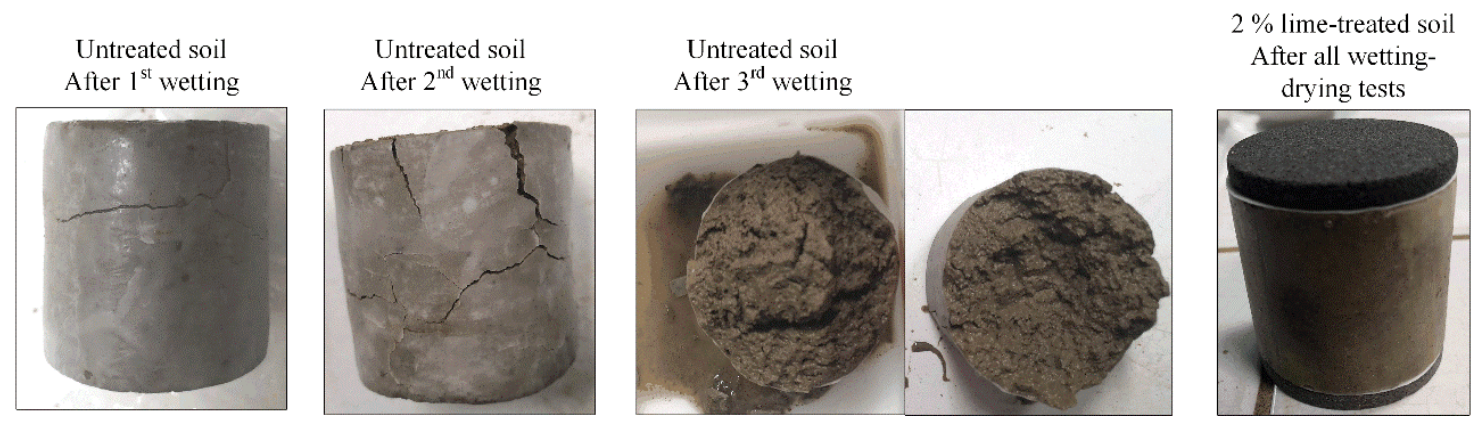

Fig. 7. The photos of specimens at different wetting-drying states.

Figures $8 \mathrm{a}$ and $8 \mathrm{~b}$ present the variations of $G_{\max }$ with time under wetting-drying cycles for the untreated specimens S0.4 and S5, respectively. The corresponding water content at each wetting-drying stages are also presented. The starting point of $G_{\max }(t=0)$ corresponded to the last point in Fig. 6, and the starting point of water content was the value of compacted water 
content. It appears from Fig. 8 that, during wetting-drying cycles, the wetting fluid effect on the $G_{\max }$ was insignificant for the untreated specimens. For both specimens S0.4 and S5, the first wetting reduced $G_{\max }$ values from $23 \mathrm{MPa}$ to $10 \mathrm{MPa}$. Despite of some cracks on the surface of untreated specimens, $G_{\max }$ could recover to the value of $23 \mathrm{MPa}$ upon the subsequent drying. In the second wetting-drying cycle, the $G_{\max }$ variations were similar to those in the first cycle. The untreated specimens were destroyed after the third wetting and no further measurement of $G_{\max }$ was possible. When the water contents were kept unchanged ( $w=17 \%$ in drying stage; $w$ $=25 \%$ in wetting stage), the $G_{\max }$ of untreated specimens varied slightly with time.
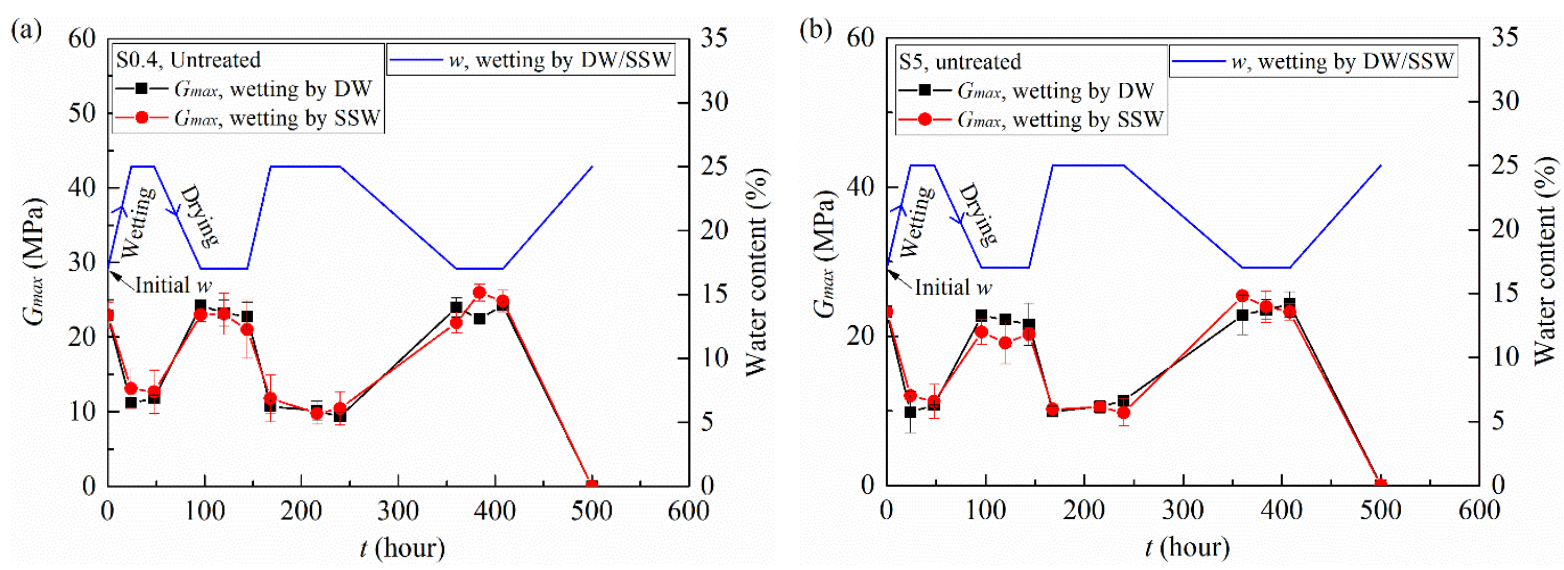

Fig. 8. $G_{\max }$ changes during wetting-drying cycles for untreated soil: (a) S0.4; (b) S5.

The changes in $G_{\max }$ with time under wetting-drying cycles are plotted in Figs. 9a and $9 \mathrm{~b}$ for the lime-treated specimens S0.4 and S5, respectively. Because of the limited number of replicated specimens, the two replicated specimens compacted on dry side $(w=17 \%)$ were wetted by deionized water, and the two replicated specimens compacted on wet side $(w=19 \%)$ were wetted by synthetic seawater. For both lime-treated specimens S0.4 and S5, $G_{\max }$ decreased with wetting, while it increased in the subsequent drying process, regardless of the wetting fluid used. Generally, upon wetting or drying, $G_{\max }$ increased with wetting-drying cycles for the lime-treated specimens wetted by synthetic seawater, whereas it decreased slightly for the specimens wetted by deionized water. Moreover, the specimens wetted by synthetic seawater had higher $G_{\max }$ as compared to the specimens wetted by deionized water, especially for specimens S0.4 at both wetting and drying conditions (Fig. 9a). After a total of seven wetting-drying cycles, all the lime-treated specimens were subjected to an intensive drying process. It appears that $G_{\max }$ increased significantly to around $120 \sim 126 \mathrm{MPa}$ at $8 \%$ water content, then it continued to increase to $150 \sim 160 \mathrm{MPa}$ with decreasing water content to $3 \%$, regardless of the soil aggregate sizes (S0.4 and S5) and the wetting fluids (deionized water 
and synthetic seawater). Rewetting the specimens from water content of $3 \%$ to $21 \%$ reduced $G_{\max }$ to the values at the seventh wetting stage (20 23 MPa for specimens wetted by deionized water, $26 \sim 30 \mathrm{MPa}$ for specimens wetted by synthetic seawater).
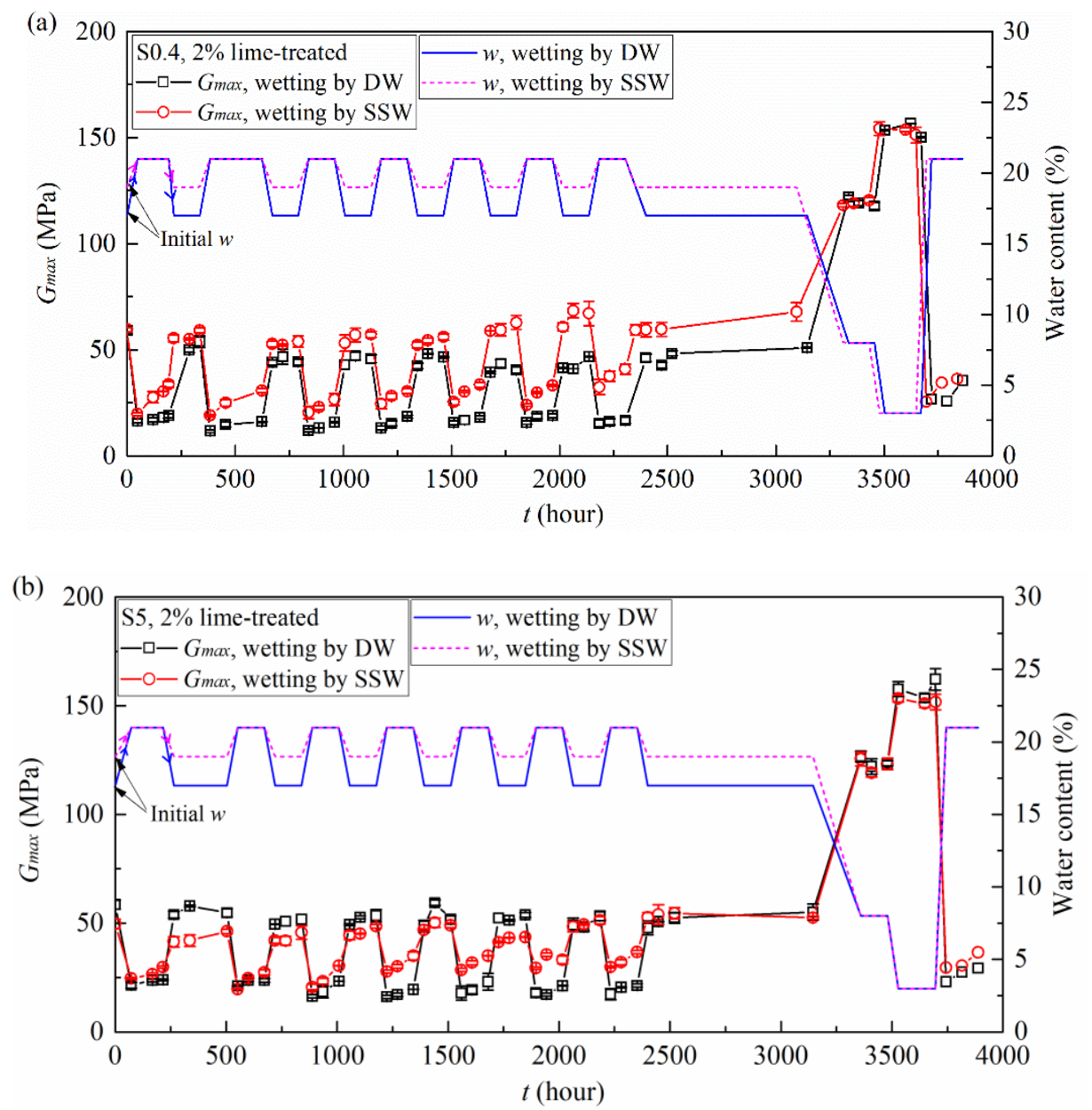

Fig. 9. $G_{\max }$ changes during wetting-drying cycles for lime-treated soil: (a) S0.4; (b) S5.

It is worth noting that, when the specimens were maintained at the end of wetting stage or drying stage, $G_{\max }$ increased significantly over time for the specimens wetted by synthetic seawater, whereas it increased slightly in the case of wetting by deionized water (Fig. 9a and 9b). To characterise the $G_{\max }$ variations, the increase of $G_{\max }\left(\Delta G_{\max }\right)$ at each wetting or drying stage was calculated, as follows (Eq. 3):

$$
\Delta G_{\max }=G_{\max L_{i W / D}}-G_{\max F_{i W / D}}
$$

where $G_{\text {maxFiw/D }}$ is the first measured value at number $i$ wetting or drying stage, and $G_{\text {maxLiw/D }}$ is the last measured value at number $i$ wetting or drying stage. 
The increase of $G_{\max }$ against the number of cycles are plotted in Figs. 10a and 10b for the limetreated specimens S0.4 and S5 in wetting stage, and in Figs. 10c and 10d in drying stage, respectively. It appears that, when the water content was maintained at the high value in wetting stage (Figs. 10a and 10b), the specimens wetted by synthetic seawater had higher increase of $G_{\max }$ as compared to the specimens wetted by deionized water. Nevertheless, under the drying condition, the wetting fluid effect on the increase of $G_{\max }$ was negligible (Figs. 10c and 10d). For the lime-treated specimens wetted by synthetic seawater, the increase of $G_{\max }$ was much more significant for the specimens under wetting condition $(5 \sim 15 \mathrm{MPa})$ than for the specimens under drying condition $(0 \sim 5 \mathrm{MPa})$.
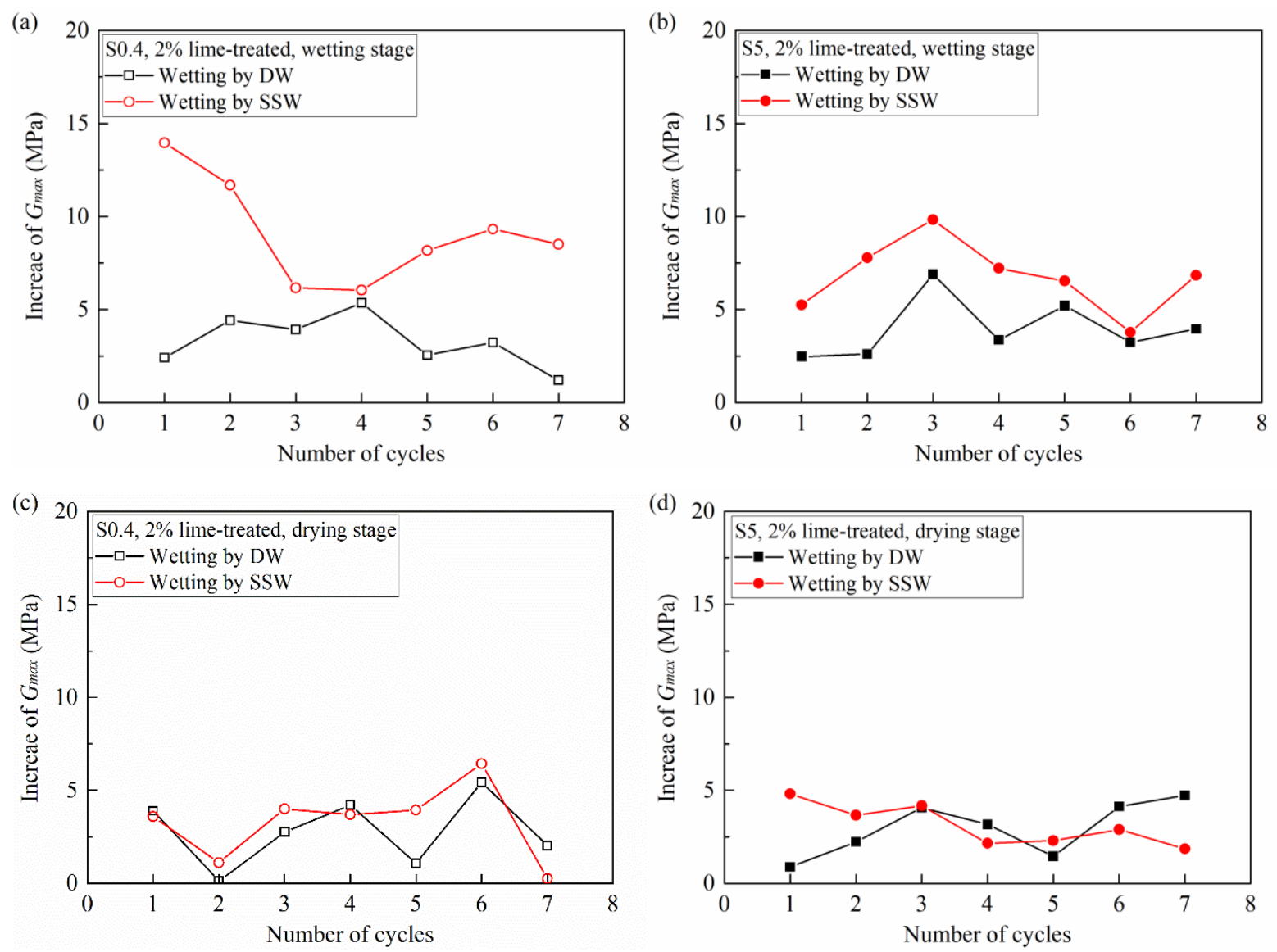

Fig. 10. Increase of $G_{\max }$ with wetting-drying cycles.

\subsection{MIP results}

Figure 11 presents the MIP results of lime-treated specimens S0.4 subjected to different wetting-drying cycles. It appears from Fig. 11a that the specimens at water contents of $17 \%$ and $21 \%$ exhibited bi-modal pore size distribution characteristics with two populations of micropores and macro-pores. The first wetting cycle resulted in an increase in the micro-pore modal 
size and a decrease in the macro-pore modal size. Upon subsequent drying (from B to C), the modal size of micro-pores recovered to the value of specimen "A", while that of macro-pores was enlarged to a higher value. The second wetting cycle made the modal sizes of micro-pores and macro-pores of specimen "D" shift to the similar values of specimen "B". Similarly, the pore size distribution curve of specimen " $E$ " at the seventh wetting stage approached the curves of specimens "B" and "D", suggesting that the variations of pore size distribution of limetreated specimens were almost reversible under cyclic wetting-drying. As shown in Fig. 11b, the pore size distribution curves varied significantly with the intensive drying: the pore size distribution changed from bi-modal pattern to tri-modal pattern with drying to $8 \%$ water content, and finally retrieved the bi-modal pattern with further drying to $3 \%$ water content. As expected, upon the subsequent wetting, the tri-modal pore size distribution pattern at $8 \%$ water content recovered to bi-modal pattern (Fig. 11c). Nevertheless, slight irreversible changes were observed for specimens "I", "J" and "K" after rewetting - the pore size distribution shifted rightwards in turn with the specimens being previously dried to the water contents of $17 \%, 8 \%$ and $3 \%$ (Fig. 11c).
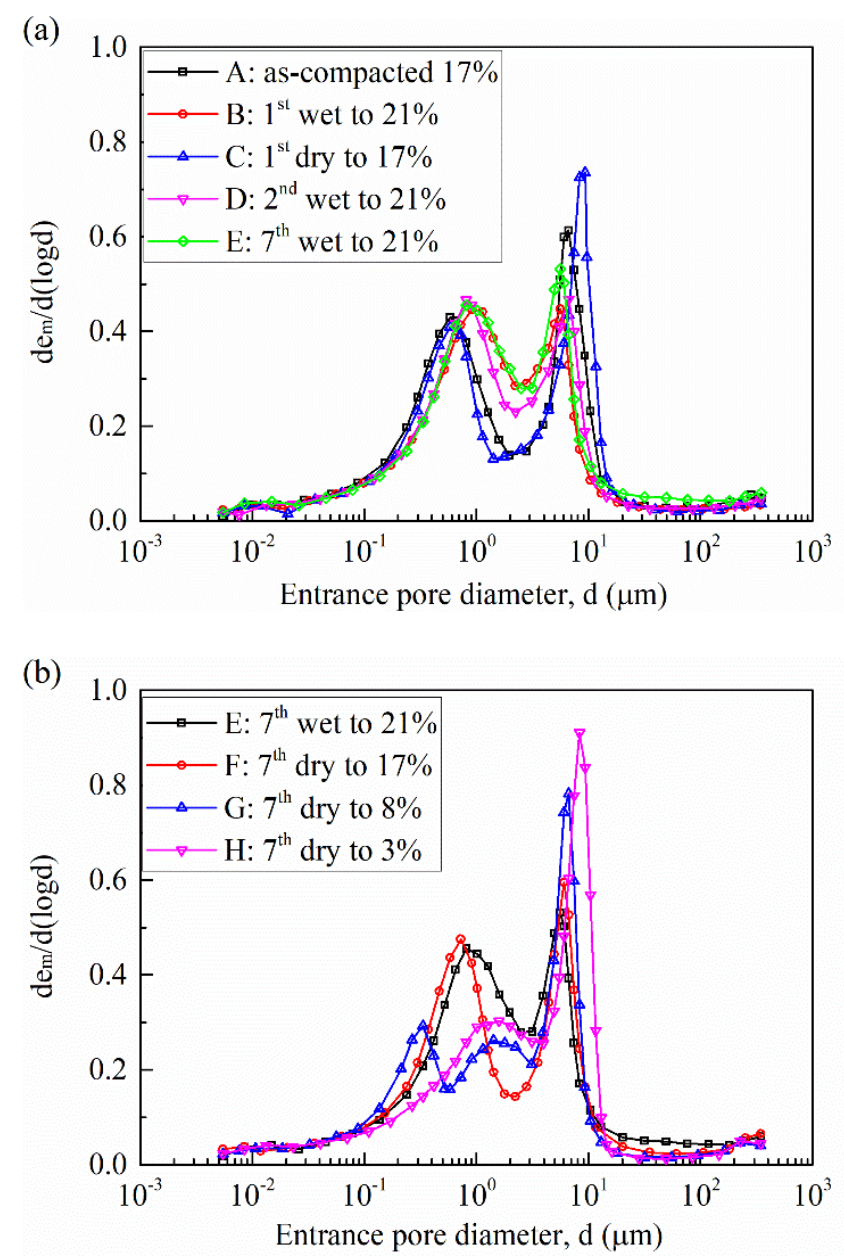


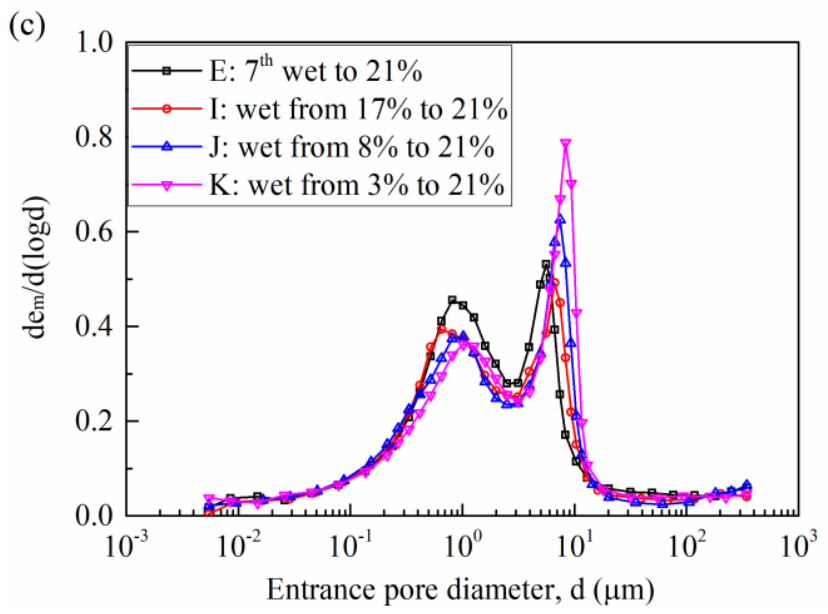

Fig. 11. Pore size distributions of lime-treated specimens (S0.4, $t=600 \mathrm{~d}$ ) subjected to wetting-drying cycles.

\section{Discussions}

\subsection{Curing time effect on the $G_{\max }$}

Figure 6 showed that, after compaction, the $G_{\max }$ of lime-treated soil was around $6 \mathrm{MPa}$ higher than that of untreated soil, whatever the maximum soil aggregate size. This can be attributed to the increase of suction resulting from the lime-treatment on the one hand, and to the flocculation of soil particles resulting from the cation exchange on the other hand (Tang et al., 2011a; Wang et al., 2020). Indeed, the matric suction was found to be $41 \mathrm{kPa}$ for lime-treated specimens at curing time of 14 days (14 days for filter paper measurement after compaction) that was higher than that of untreated specimens (22 kPa according toYing et al., 2021c). For the lime-treated soil, the flocculation of soil particles gave rise to an increase of $G_{\max }$ in short curing period, while the increase of $G_{\max }$ in the long term was due to the formation of cementitious compounds in the pozzolanic reaction, which bonded the adjacent soil particles and thus improved the soil stiffness (Tang et al., 2011a; Wang et al., 2020). Unlike the lime-treated soil, the $G_{\max }$ of untreated soil increased slightly over curing, which can be attributed to the aging effect of compacted soil: the amount of micro-pores increased with the exchange of water between the micro-pores and macro-pores with time (Delage et al., 2006), which could increase the soil capillarity, and hence soil matric suction and stiffness.

\subsection{Factors influencing the stabilized values of $G_{\max }$}

For the lime-treated specimens S0.4, the stabilized values of $G_{\max }$ were found to be insensitive to the moulding water content (Fig. 6a), in agreement with the observation by Tang et al. (2011a). 
However, in the case of lime-treated specimens S5, the specimens compacted dry of optimum had relatively higher $G_{\max }$ than the specimens compacted wet of optimum (Fig. 6b), which was consistent with the observations made by Wang et al. (2020). Tang et al. (2011a) and Wang et al. (2020) indicated that the $G_{\max }$ of dry side specimens was mainly governed by the contact surface of aggregates and cementitious bonds, while that of wet side specimens was dominated by suction and cementitious bonds. Ying et al. (2020) conducted MIP tests on the lime-treated specimens (the same silt as in this study) which were compacted on both dry and wet sides. They found that both dry and wet specimens exhibited aggregated structures with two populations of micro-pores and macro-pores, giving rise to similar contact surfaces of aggregates for dry and wet side specimens. Thus, the suction and cementitious bonds seemed to be the main factors influencing $G_{\max }$ for this lime-treated silt.

For a given soil, the formation of cementitious compounds was affected by the soil aggregate size and the moulding water content. It was reported that sufficient water was needed for the hydration and pozzolanic reaction in lime-treated soil (Muntohar et al., 2013; Russo and Modoni, 2013; Anggraini et al., 2016). This implied that much cementitious compounds might be formed for the specimens compacted wet of optimum, contributing more to the soil stiffness. However, the specimens compacted wet of optimum had lower suction, leading to a lower soil stiffness. Thus, for the lime-treated specimens compacted wet of optimum, there was competition between the positive contribution from the more significant formation of cementitious bonds and the negative contribution from the lower suction. Besides, the specimens with smaller aggregate size had a larger total contact surface between soil and lime, probably producing much more cementitious compounds (Tang et al., 2011a; Wang et al., 2017b). Thus, it can be inferred that, for specimens S0.4 compacted wet of optimum, much more cementitious bonds were created, which could compensate the degradation of $G_{\max }$ caused by the lower suction, making $G_{\max }$ increase to the level of specimens S0.4 compacted dry of optimum over curing. Nevertheless, as regards specimens S5, the promotion of pozzolanic reaction for the wet specimens was limited due to the smaller contact surface between soil and lime. Therefore, the lower suction for specimens S5 compacted wet of optimum led to lower $G_{\text {max }}$ as compared to specimens S5 compacted dry of optimum.

\subsection{Wetting-drying cycle effect on the microstructure and $G_{\max }$}

When the specimens were exposed to wetting, the untreated specimens could uptake more water than lime-treated soil, in agreement with the results obtained by Stoltz et al. (2012). For 
untreated soil, wetting induced a significant expansion of soil specimens, giving rise to an appreciable increase of water content to $25 \%$. On the contrary, the swelling potential was highly inhibited by lime treatment, leading to a lower water adsorption and thus small water uptake during wetting.

The untreated specimens were easily softened and damaged with wetting, while the lime-treated specimens survived from the cyclic wetting-drying tests and $G_{\max }$ seemed to undergo repeated decreasing and increasing cycles along the wetting and drying paths. This indicated that the lime treatment indeed improved the soil workability and long-term durability. The repetitive variations of $G_{\max }$ can be attributed to the suction effect induced from the water content variations (Ng et al., 2009; Tang et al., 2011a; Heitor et al., 2015; Ngoc et al., 2019). Generally, soil suction was reduced with wetting, leading to a reduction of soil stiffness. Nevertheless, upon drying, soil suction was increased. This corresponded to an increase in the mean effective stress which held the soil particles together and enhanced the soil mechanical behaviour, giving rise to an increase of $G_{\max }(\mathrm{Ng}$ et al., 2009; Ngoc et al. 2019). The total suction was measured by chilled-mirror dew-point hygrometer (WP4C) for the lime-treated specimens S0.4 $(t=90$ days) with two different soil salinities of $0.05 \%$ ( $\mathrm{g}$ of salt $/ \mathrm{kg}$ of dry soil) and $6.8 \%$, and for the lime-treated specimens S0.4 ( $t=90$ days $)$ subjected to seven wetting-drying cycles. Note that the soil salinity of $6.8 \%$ corresponded to the salt concentration of $35 \mathrm{~g} / \mathrm{L}$ in soil pore water, which was also the concentration of synthetic seawater. The osmotic suction of synthetic seawater was estimated at $2.4 \mathrm{MPa}$ by the WP4C device. The total suctions were found to be $0.8 \mathrm{MPa}$ and 3.2 MPa for the lime-treated specimens S0.4 ( $t=90$ days) with soil salinities of $0.05 \%$ and $6.8 \%$, respectively. For the specimens at the end of the seventh drying cycle, the total suctions were found to be 0.9 MPa for the specimens with deionized water, and $3.2 \mathrm{MPa}$ in the case of synthetic seawater. This indicated that the total suctions of specimens after seven wetting-drying cycles were approximately equivalent to the values of as-compacted specimens (wetted by deionized water against soil salinity of $0.05 \%$, wetted by synthetic seawater against soil salinity of $6.8 \%$ ), respectively. This suggested that the suction variations were almost reversible during wetting-drying cycles as water content varied slightly in the range of $17 \%$ to $21 \%$, in agreement with the $G_{\max }$ changes. It is also interesting to note that the difference between the total suctions of specimens with two different salinities $(0.05 \%$ against $6.8 \%$, wetted by deionized water against by synthetic seawater) was around $2.3 \sim 2.4 \mathrm{MPa}$ which was exactly equal to the osmotic suction of synthetic seawater, indicating that there was no precipitated salts as water content varied between $17 \%$ and $21 \%$. 
The changes in $G_{\max }$ of lime-treated specimens during wetting-drying cycles were in agreement with the microstructure variations in which the pore size distribution showed almost reversible pattern in the total seven wetting-drying cycles with the water content varying from $17 \%$ to $21 \%$ (Fig. 11a). During wetting, the expansion of soil aggregates led to an increase of the micro-pore size and a decrease of macro-pore size, while the subsequent drying resulted in the shrinkage of soil aggregates which made the pore size distribution recover to the state of specimens at water content of $17 \%$. The almost reversible fabric changes of lime-treated soil were mainly attributed to the coarser aggregates and the cementitious bonds resulting from the soil-lime reaction, which could maintain the soil microstructure stable during wetting-drying cycles with water content varying slightly between $17 \%$ and $21 \%$, and thus the repetitive decreasing and increasing phenomena of $G_{\max }$. Nevertheless, the intensive drying to the water contents of $8 \%$ and $3 \%$ altered the microstructure significantly, which could be attributed to the shrinkagerelated cracking of the clay part (Sun and Cui, 2018; Ying et al., 2021d). Indeed, some fissures/cracks would occur during drying, as the rising tensile stress exceeded the tensile strength or the soil shrinkage was constrained by boundary conditions (Péron et al., 2009; Tang et al., 2011b; Romero 2013). As shown in Fig. 11b, the pore size distribution changed from bimodal characteristics $(w=17 \%)$ to tri-modal pattern $(w=8 \%)$ with three populations of nanopores, micro-pores and macro-pores, in which the nano-pores were mostly composed of dryinginduced nano-fissures. With further drying to $3 \%$ water content, the nano-pores became lager and lager with the continuous shrinkage of the clay part, making the nano-pores disappear. Tang et al. (2011a) worked on a lime-treated silt and reported that the drying-induced micro-cracks would result in a decrease of $G_{\max }$. It appears from Fig. 9 that $G_{\max }$ increased significantly with the specimens being dried to $8 \%$ and $3 \%$, indicating that the soil suction played a dominant role in the increase of $G_{\max }$ which prevailed facing the adverse effect of drying-induced fissures. Ying et al. (2021a) performed salinity assessment on this silt (soil salinity $=6.32 \%$ ) with decreasing water content and reported that when the water content decreased to $8 \%$, some salts started to precipitate. It can be inferred that for this lime-treated silt wetted by synthetic seawater, some salts could precipitate with more intensive drying. This salt precipitation between soil particles played the role of bridge connection, contributing to soil stiffness (Truong et al., 2012). The subsequent wetting of specimens induced the healing of drying-induced fissures, as evidenced clearly by the disappearance of nano-pores on the pore size distribution curves when the specimen was wetted from water content of $8 \%$ to $21 \%$. The similar phenomena of fissure healing were observed on the other specimens upon wetting which were previously dried to $17 \%$ and $3 \%$ water contents. This rewetting made $G_{\max }$ approach the values at wetting state 
prior to the intensive drying. This was inconsistent with the results obtained by Tang et al. (2011a), who observed a significant reduction of $G_{\max }$ during the last wetting path after an intensive drying.

\subsection{Wetting fluid effect on the $G_{\max }$ during wetting-drying cycles}

As shown in Fig. 10, the increase of $G_{\max }$ with time at the end of each wetting or drying stage was much significant for the specimens wetted by synthetic seawater as compared to those wetted by deionized water. This indicated that synthetic seawater might enhance the soil stiffness. The similar results were obtained by Ying et al. (2021b) on untreated soil - the $G_{\max }$ of saline soil was higher than those of saltless soil due to the slight modification of microstructure by salts. Besides, the production of cementitious compounds might be promoted by salts. Indeed, Ramesh et al. (1999) reported that the sodium salts in fly ash-lime mixtures promoted the formation of sodium calcium silicate hydrate, and Saldanha et al. (2017) indicated that $\mathrm{NaCl}$ within $1 \%$ increased the dissolution of lime and gave rise to an increase of unconfined compressive strength. Thus, it can be inferred that the cations in synthetic seawater could promote pozzolanic reaction, and hence the formation of cementitious compounds. Nevertheless, it was also reported that wetting-drying cycles would resulted in a breakage or softening of the bonds of cementitious compounds, leading to a decrease of soil strength (Rao et al., 2001; Guney et al., 2007; Stoltz et al., 2014; Rosone et al., 2018; Cuisinier et al., 2020). For the specimens wetted by synthetic seawater, upon wetting $(w=21 \%)$ or $\operatorname{drying}(w=$ compacted water content), $G_{\max }$ followed an increasing trend during wetting-drying cycles (Fig. 9), suggesting that the contribution of cementitious compounds to $G_{\max }$ exceeded the reduction caused by the breakage or the softening of cementitious bonds. Nevertheless, in the case of the specimens wetted by deionized water, $G_{\max }$ followed a decreasing trend with wetting-drying cycles, as the destruction or softening of bonds prevailed facing the positive effect of cementitious compounds.

\subsection{Aggregate size effect on the $G_{\max }$ during wetting-drying cycles}

As mentioned previously, the specimens S0.4 with smaller aggregates had larger contact surface for soil-lime reaction. Thus, the promotion of pozzolanic reaction by synthetic seawater was much more significant for specimens S0.4 than for specimens S5. Besides, when the specimens were wetted by synthetic seawater, the thickness of diffuse double layer of clay fraction should decrease, causing a reduction of repulsive force, which in turn, led to an increase of net 
attractive force (Mitchell and Soga, 2005; Israelachvili, 2011). This promoted the soil particles to associate with each other at a lower inter-particle distance (Sridharan and Jayadeva, 1982; Thyagaraj and Salini, 2015). Consequently, the $G_{\max }$ values of specimens S0.4 wetted by synthetic seawater were rather higher than those of the specimens wetted by deionized water (Fig. 9a). However, the larger aggregates of specimens S5 exhibited smaller contact surface between soil and lime, limiting the promotion of pozzolanic reaction by salts. Furthermore, the soil aggregation induced by salts can be neglected as compared to the initial larger aggregates in specimens S5. Thus, the difference between $G_{\max }$ of specimens S5 wetted by synthetic seawater and deionized water was insignificant (Fig. 9b).

\section{Conclusions}

The changes in small strain shear modulus $\left(G_{\max }\right)$ of untreated and lime-treated soils during curing and cyclic wetting-drying were studied, with consideration of the effects of maximum soil aggregate size and wetting fluid. The microstructure observations were made using MIP technique to investigate the effect of wetting-drying cycles on the soil fabric alteration. Based on the obtained results, the following conclusions were drawn:

(1) Lime treatment significantly increased $G_{\max }$ of soil due to the effects of soil flocculation and the production of cementitious compounds, and the $G_{\max }$ of untreated soil increased slightly due to the aging effect which would increase the soil suction slightly. The stabilized $G_{\max }$ values were independent of moulding water content for the treated specimens S0.4, because the much more production of cementitious compounds on wet side of optimum compensated the degradation of $G_{\max }$ induced from the lower suction. For the specimens S5 compacted on wet side, the lower suction effect prevailed the promotion of pozzolanic reaction by higher water content due to the smaller contact surface for soil-lime reaction, leading to lower $G_{\max }$ as compared to the specimens S5 compacted on dry side.

(2) The wetting-drying cycles had a significantly detrimental effect on the untreated specimens that induced some cracks on the soil surface and destroyed the soil samples at the third wetting cycle, whereas no significant volume variations and cracks were observed on lime-treated specimens, indicating the beneficiary effect of lime treatment in terms of long-term durability. The microstructure characterization showed that the pore size distributions of lime-treated soil were almost reversible with water content varying from $17 \%$ to $21 \%$. The subsequent intensive drying altered the pore size distribution significantly, which changed from bi-modal pattern to 
tri-modal pattern with drying from water content of $17 \%$ to $8 \%$, and finally recovered to bimodal pattern as water content decreased to $3 \%$. Such fabric variations could be attributed to the clay shrinkage, producing some drying-induced fissures. However, the rewetting of limetreated specimens could induce healing of fissures, making the pore size distribution exhibit similar pattern.

(3) Due to the almost reversible microstructure variations, the $G_{\max }$ of lime-treated soil followed the repeated decreasing and increasing trends with wetting and drying paths. Wetting reduced the soil matric suction and thus the soil stiffness, while drying increased the soil suction and stiffness. Upon intensive drying, $G_{\max }$ increased significantly, indicating that the negative effect of the drying-induced fissures can be neglected. As the fissures were healed, the rewetting led the $G_{\max }$ to approach the values at wetting state prior to the intensive drying.

(4) At each wetting or drying stage, $G_{\max }$ of lime-treated soil increased with time at the constant water content, which was attributed to the pozzolanic reaction. The increase of $G_{\max }$ was much significant for the specimens at wetting state, especially for the treated specimens wetted by synthetic seawater, suggesting that the production of cementitious compounds was promoted by salts. Nevertheless, under wetting or drying condition, $G_{\max }$ decreased slightly with the wetting-drying cycles in the case of deionized water as wetting fluid, indicating that the wettingdrying indeed induced softening of soil structure that exceeded the contribution of cementitious compounds. On the contrary, for the specimens wetted by synthetic seawater, $G_{\max }$ increased with wetting-drying cycles due to the much more significant effect of cementitious bonds.

(5) The lime-treated specimens S0.4 wetted by synthetic seawater had higher $G_{\max }$ than the specimens wetted by deionized water. By contrast, the wetting fluid had insignificant effect on $G_{\max }$ of lime-treated specimens S5. This could be attributed to the limited promotion of pozzolanic reaction by salts in specimens S5 which exhibited smaller contact surface between soil and lime, and to the negligible effect of soil aggregation induced by salts as compared to the initial lager aggregates.

\section{Author statement}

Zi Ying: Validation, Investigation, Writing - original draft. Yu-Jun Cui: Conceptualization, Methodology, Writing - review \& editing. Nadia Benahmed: Investigation, Resources. Myriam Duc: Investigation. 


\section{Declaration of competing interest}

The authors declare that they have no known competing financial interests or personal relationships that could have appeared to influence the work reported in this paper.

\section{Acknowledgements}

The authors would like to thank the China Scholarship Council (CSC). The supports provided by Ecole des Ponts ParisTech (ENPC) and INRAE are also greatly acknowledged.

\section{References}

Al-Mukhtar, M., Lasledj, A., Alcover, J.F., 2010a. Behaviour and mineralogy changes in limetreated expansive soil at $20^{\circ} \mathrm{C}$. Appl. Clay Sci. 50, 191-198. https://doi.org/10.1016/ j.clay.2010.07.023

Al-Mukhtar, M., Lasledj, A., Alcover, J. F., 2010b. Behaviour and mineralogy changes in limetreated expansive soil at $50^{\circ} \mathrm{C}$. Appl. Clay Sci. 50, 199-203. https://doi.org/10.1016/ j.clay.2010.07.022

Al-Mukhtar, M., Khattab, S., Alcover, J.F., 2012. Microstructure and geotechnical properties of lime-treated expansive clayey soil. Eng. Geol. 139/140, 17-27. https://doi.org/10.1016/j. enggeo.2012.04.004

Al-Swaidani, A., Hammoud, I., Meziab, A., 2016. Effect of adding natural pozzolana on geotechnical properties of lime-stabilized clayey soil. J. Rock Mech. Geotech. Eng. 8, 714725. https://doi.org/10.1016/j.jrmge.2016.04.002

Aldaood, A., Bouasker, M., Al-mukhtar, M., 2014. Impact of wetting - drying cycles on the microstructure and mechanical properties of lime-stabilized gypseous soils. Eng. Geol. 174, 11-21. https://doi.org/10.1016/j.enggeo.2014.03.002

Anggraini, V., Asadi, A., Farzadnia, N., Jahangirian, H., Huat, B.B.K., 2016. Reinforcement Benefits of Nanomodified Coir Fiber in Lime-Treated Marine Clay. J. Mater. Civ. Eng. 28, 06016005. https://doi.org/10.1061/(asce)mt.1943-5533.0001516

ASTM D6276-19, 2019. Standard Test Method for Using pH to Estimate the Soil-Lime Proportion Requirement for Soil Stabilization. ASTM International, West Conshohocken, PA.

Bell, F.G., 1989. Lime stabilisation of clay soils. Bull. Int. Assoc. Eng. Geol 39, 67-74. https://doi.org/ 10.1007/BF02592537

Bell, F.G., 1996. Lime stabilization of clay minerals and soils. Eng. Geol. 42, 223-237. https://doi.org/10.1016/0013-7952(96)00028-2

Chakraborty, S., Banerjee, A., Das, J.T., Mosadegh, L., Puppala, A.J., 2018. Impact of variation of small strain shear modulus on seismic slope stability analysis of a levee: A Sensitivity Analysis. In IFCEE 2018, 302-313. https://doi.org/10.1061/9780784481608.029 
Cuisinier, O., Deneele, D., 2008. Impact of cyclic wetting and drying on the swelling properties of a lime-treated expansive clay. In: Jourées Nationales de Géotechnique et de Géologie de l'Ingénieur JNGG'08, Nantes, pp. 18-20.

Cuisinier, O., Masrouri, F., Mehenni, A., 2020. Alteration of the hydromechanical performances of a stabilized compacted soil exposed to successive wetting-drying cycles. J. Mater. Civ. Eng. 32, 04020349. https://doi.org/10.1061/(asce)mt.1943-5533.0003270

Delage, P., Marcial, D., Cui, Y.J., Ruiz, X., 2006. Ageing effects in a compacted bentonite: A microstructure approach. Géotechnique 56, 291-304. https://doi.org/10.1680/geot. 2006.56.5.291

Di Sante, M., Fratalocchi, E., Mazzieri, F., Pasqualini, E., 2014. Time of reactions in a lime treated clayey soil and influence of curing conditions on its microstructure and behaviour. Appl. Clay Sci. 99, 100-109. https://doi.org/10.1016/j.clay.2014.06.018

Dong, J., 2013. Investigation of aggregates size effect on the stiffness of lime and/or cement treated soil: from laboratory to field conditions. PhD Dissertation. France, Ecole des Ponts ParisTech.

Estabragh, A.R., Moghadas, M., Javadi, A.A., 2013. Effect of different types of wetting fluids on the behaviour of expansive soil during wetting and drying. Soils Found. 53, 617-627. https://doi.org/10.1016/j.sandf.2013.08.001

French standard AFNOR NF P 18-837. 1993. Standard for special products for hydraulic concrete construction-Hydraulic binder based needling and/or sealing products-Testing of resistance against seawater and/or water with high sulphate contents.

Guney, Y., Sari, D., Cetin, M., Tuncan, M., 2007. Impact of cyclic wetting-drying on swelling behavior of lime-stabilized soil. Build. Environ. 42, 681-688. https://doi.org/10.1016/j.buildenv.2005.10.035

Heitor, A., Indraratna, B., Rujikiatkamjorn, C., 2015. The role of compaction energy on the small strain properties of a compacted silty sand subjected to drying-wetting cycles. Géotechnique. 65 (9), 717-727. https://doi.org/10.1680/geot.14.P.053

Israelachvili, J.N., 2011. Intermolecular and surface forces. 3rd edn. Academic press.

Khattab, S.A.A., Fleureau, J., 2007. Long-Term Stability Characteristics of a lime-treated plasric soil. J. Mater. Civ. Eng. 19(4), 358-366. https://doi.org/10.1061/(ASCE)08991561(2007)19:4(358)

Khosravi, A., Hashemi, A., Ghadirianniari, S., Khosravi, M., 2020. Variation of small-strain shear modulus of unsaturated silt under successive cycles of drying and wetting. J. Geotech. Geoenviron. Eng. 146, 1-13. https://doi.org/10.1061/(ASCE)GT.1943-5606.0002275

Lee, J. S., Santamarina, J. C., 2005. Bender elements: performance and signal interpretation. J. Geotech. Geoenviron. Eng. 131(9), 1063-1070. https://doi.org/10.1061/(ASCE)10900241(2005)131:9(1063)

Locat, J., Berube, M.A., Choquette, M., 1990. Laboratory investigations on the lime stabilization of sensitive clays: shear strength development. Can. Geotech. J. 27, 294-304. https://doi.org/10.1139/t90-040

Mitchell, J.K., Soga, K., 2005. Fundamentals of soil behaviour. 3rd edn. John Wiley \&Sonc, Inc. 
Muntohar, A.S., Widianti, A., Hartono, E., Diana, W., 2013. Engineering properties of silty soil stabilized with lime and rice husk ash and reinforced with waste plastic fiber. J. Mater. Civ. Eng. 25, 1260-1270. https://doi.org/10.1061/(asce)mt.1943-5533.0000659

Nabil, M., Mustapha, A., Rios, S., 2020. Impact of wetting-drying cycles on the mechanical properties of lime-stabilized soils. Int. J. Pavement Res. Technol. 13, 83-92. https://doi.org/10.1007/s42947-019-0088-y

Ng, C.W.W., Xu, J., Yung, S.Y., 2009. Effects of wetting-drying and stress ratio on anisotropic stiffness of an unsaturated soil at very small strains. Can. Geotech. J. 46, 1062-1076. https://doi.org/10.1139/T09-043

Ng, C.W.W., Yung, S.Y., 2008. Determination of the anisotropic shear stiffness of an unsaturated decomposed soil. Géotechnique. 58(1), 23-35. https://doi.org/10.1680/ geot.2008.58.1.23

Ngoc, T.P., Fatahi, B., Khabbaz, H., 2019. Impacts of Drying-Wetting and Loading-Unloading Cycles on Small Strain Shear Modulus of Unsaturated Soils. Int. J. Geomech. 19(8), 04019090. https://doi.org/10.1061/(ASCE)GM.1943-5622.0001463

Péron, H., Hueckel, T., Laloui, L., Hu, L.B., 2009. Fundamentals of desiccation cracking of fine-grained soils: Experimental characterisation and mechanisms identification. Can. Geotech. J. 46, 1177-1201. https://doi.org/10.1139/T09-054

Puppala, A.J., Kadam, R., Madhyannapu, R.S., Hoyos, L.R. 2006. Small-strain shear moduli of chemically stabilized sulfate-bearing cohesive soils. J. Geotech. Geoenviron. Eng. 132(3), 322-336. https://doi.org/10.1061/(ASCE)1090-0241(2006)132:3(322)

Ramesh, H.N., Mohan, M.S., Sivapullaiah, P. V., 1999. Improvement of strength of fly ash with lime and sodium salts. Gr. Improv. 3, 163-167. https://doi.org/10.1680/gi.1999.030403

Rao, S.M., Reddy, B.V.V., Muttharam, M., 2001. The impact of cyclic wetting and drying on the swelling behaviour of stabilized expansive soils. Eng. Geol. 60, 223-233. https://doi.org/10.1016/S0013-7952(00)00103-4

Rao, S.M., Shivananda, P., 2005. Compressibility behaviour of lime-stabilized clay. Geotech. Geol. Eng. 23, 309-319. https://doi.org/10.1007/s10706-004-1608-2

Romero, E., 2013. A microstructural insight into compacted clayey soils and their hydraulic properties. Eng. Geol. 165, 3-19. https://doi.org/10.1016/j.enggeo.2013.05.024

Rosone, M., Airò Farulla, C., Ferrari, A., Torta, C., Celauro, C., 2016. Suction controlled drying and wetting cycle effects on the volumetric behaviour of a lime-treated high plasticity clay. E3S Web Conf. 9, 0-5. https://doi.org/10.1051/e3sconf/20160914020

Rosone, M., Ferrari, A., Celauro, C., 2018. On the hydro-mechanical behaviour of a limetreated embankment during wetting and drying cycles. Geomech. Energy Environ. 14, 4860. https://doi.org/10.1016/j.gete.2017.11.001

Russo, G., Modoni, G., 2013. Fabric changes induced by lime addition on a compacted alluvial soil. Geotech. Lett. 3, 93-97. https://doi.org/10.1680/geolett.13.026

Saldanha, R.B., Scheuermann Filho, H.C., Ribeiro, J.L.D., Consoli, N.C., 2017. Modelling the influence of density, curing time, amounts of lime and sodium chloride on the durability of compacted geopolymers monolithic walls. Constr. Build. Mater. 136, 65-72. https://doi.org/10.1016/j.conbuildmat.2017.01.023

Santamarina, J.C., Klein, K.A., Wang, Y.H., Prencke, E., 2002. Specific surface: Determination and relevance. Can. Geotech. J. 39, 233-241. https://doi.org/10.1139/t01-077 
Sivapullaiah, P. V., Sridharan, A., Ramesh, H.N., 2000. Strength behaviour of lime-treated soils in the presence of sulphate. Can. Geotech. J. 37, 1358-1367. https://doi.org/10.1139/t00052

Sridharan, A., Jayadeva, M.S., 1982. Double layer theory and compressibility of clays. Géotechnique 32, 133-144. https://doi.org/10.1680/geot.1982.32.2.133

Stoltz, G., Cuisinier, O., Masrouri, F., 2012. Multi-scale analysis of the swelling and shrinkage of a lime-treated expansive clayey soil. Appl. Clay Sci. 61, 44-51. https://doi.org/10.1016/ j.clay.2012.04.001

Stoltz, G., Cuisinier, O., Masrouri, F., 2014. Weathering of a lime-treated clayey soil by drying and wetting cycles. Eng. Geol. 181, 281-289. https://doi.org/10.1016/j.enggeo.2014.08. 013

Sun, W.J., Cui, Y.J., 2018. Investigating the microstructure changes for silty soil during drying. Géotechnique 68, 370-373. https://doi.org/10.1680/jgeot.16.P.165

Tang, A.M., Vu, M.N., Cui, Y.J., 2011a. Effects of the maximum soil aggregates size and cyclic wetting-drying on the stiffness of a lime-treated clayey soil. Géotechnique 61, 421-429. https://doi.org/10.1680/geot.SIP11.005

Tang, C.S., Shi, B., Liu, C., Suo, W. Bin, Gao, L., 2011b. Experimental characterization of shrinkage and desiccation cracking in thin clay layer. Appl. Clay Sci. 52, 69-77. https://doi.org/10.1016/j.clay.2011.01.032

Thyagaraj, T., Salini, U., 2015. Effect of pore fluid osmotic suction on matric and total suctions of compacted clay. Géotechnique 65, 952-960. https://doi.org/10.1680/jgeot.14.P.210

Truong, Q.H., Lee, C., Kim, Y.U., Lee, J.S., 2012. Small strain stiffness of salt-cemented granular media under low confinement. Géotechnique 62, 949-953. https://doi.org/10.1680/geot.10.T.004

Vitale, E., Deneele, D., Paris, M., Russo, G., 2017. Multi-scale analysis and time evolution of pozzolanic activity of lime treated clays. Appl. Clay Sci. 141, 36-45. https://doi.org/10.1016/j.clay.2017.02.013

Wang, Q., Cui, Y.J., Tang, A.M., Li, X.L., Ye, W.M., 2014. Time-and density-dependent microstructure features of compacted bentonite. Soils Found. 54(4), 657-666. https://doi.org/10.1016/j.sandf. 2014.06.021

Wang, Y.J., Cui, Y.J., Tang, A.M., Benahmed, N., Duc, M., 2017a. Effects of aggregate size on the compressibility and air permeability of lime-treated fine-grained soil. Eng. Geol. 228, 167-172. https://doi.org/10.1016/j.enggeo.2017.08.005

Wang, Y.J., Duc, M., Cui, Y.J., Tang, A.M., Benahmed, N., Sun, W.J., Ye, W.M., 2017b. Aggregate size effect on the development of cementitious compounds in a lime-treated soil during curing. Appl. Clay Sci. 136, 58-66. https://doi.org/10.1016/j.clay.2016.11.003

Wang, Y.J., Benahmed, N., Cui, Y. J., Tang, A. M. 2017c. A novel method for determining the small-strain shear modulus of soil using the bender elements technique. Can. Geotech. J. 54(2), 280-289. https://doi.org/10.1139/cgj-2016-0341

Wang, Y.J, Cui, Y.J., Benahmed, N., Tang, A.M., Duc, M., 2020. Changes of small strain shear modulus and suction for a lime-treated silt during curing. Géotechnique 70, 276-280. https://doi.org/10.1680/jgeot.18.T.018 
Ying, Z., Cui, Y.J., Benahmed, N., Duc, M., 2020. Changes in mineralogy and microstructure of a lime-treated silty soil during curing time. E3S Web Conf. 195. https://doi.org/10.1051/e3sconf/202019503044

Ying, Z., Duc, M., Cui, Y.J., Benahmed, N., 2021a. Salinity assessment for salted soil considering both dissolved and precipitated salts. Geotech. Test. J. 44, 130-147. https://doi.org/10.1520/GTJ20190301

Ying, Z., Cui, Y.J., Benahmed, N., Duc, M., 2021b. Salinity effect on the compaction behaviour, matric suction, stiffness and microstructure of a silty soil. J. Rock Mech. Geotech. Eng. https://doi.org/10.1016/j.jrmge.2021.01.002

Ying, Z., Cui, Y.J., Benahmed, N., Duc, M., 2021c. Changes of microstructure and water retention property of a lime-treated saline soil during curing. Acta Geotech. https://doi.org/10.1007/s11440-021-01218-5

Ying, Z., Cui, Y.J., Benahmed, N., Duc, M., 2021d. Drying effect on the microstructure of compacted salted soil. Géotechnique. https://doi.org/10.1680/jgeot.20.P.319

Zeng, L.L., Cui, Y.J., Conil, N., Zghondi, J., Armand, G., Talandier, J., 2017. Experimental study on swelling behaviour and microstructure changes of natural stiff Teguline clays upon wetting. Can. Geotech. J. 54(5), 700-709. https://doi.org/10.1139/cgj-2016-0250

Zhou, Y.G., Chen, Y.M, 2005. Influence of seismic cyclic loading history on small strain shear modulus of saturated sands. Soil Dyn. Earthq. Eng. 25, 341-353. https://doi.org/10.1016/ j.soildyn.2005.03.001

Zeng, Z.X., Cui, Y.J., Zhang, F., Conil, N., Talandier, J., 2020. Effect of technological voids on swelling behaviour of compacted bentonite-claystone mixture. Can. Geotech. J. 57(12), 1881-1892. https://doi.org/10.1139/cgj-2019-0339. 